\title{
Pengaruh Penggunaan LKS Bahalap Terhadap Pemahaman Konsep Larutan Penyangga Pada Siswa Kelas XI MIPA SMA Negeri 3 Palangka Raya Tahun Ajaran 2018/2019
}

\author{
Elmy Noor Aisyah, Suandi Sidauruk, Ruli Meiliawati \\ Program Studi Pendidikan Kimia, FKIP Universitas Palangka Raya, Indonesia
}

\begin{abstract}
Abstrak :Penelitian merupakan penelitian deskriptif, dilaksanakan di SMA Negeri 3 Palangka Raya pada 28 siswa di kelas XI MIPA 1 SMAN 3 Palangka Raya Tahun ajaran 2018/2019. Data penelitian dijaring melalui tes, yakni 5 tahapan pembelajaran, yakni pra LKS, LKS, pasca LKS, diskusi, dan pasca diskusi. Berdasarkan hasil penelitian, pengaruh penggunaan LKS terhadap pemahaman siswa dapat disimpulkan sebagai berikut: (1) Indikator 1 mengidentifikasi sifat-sifat larutan penyangga skor rata-rata siswa $7,14 \%$ pada tahap pra LKS, meningkat menjadi 60,71\% pada tahap pasca LKS. (2) Indikator 2 skor rata-rata siswa $42,86 \%$ pada tahap pra LKS, meningkat menjadi $86,61 \%$ pada tahap pasca LKS. (3) Indikator 3 skor rata-rata siswa 39,29\% pada tahap pra LKS, meningkat menjadi $100 \%$ pada tahap pasca LKS. (5) Indikator 4 skor rata-rata siswa $26,79 \%$ pada tahap pra LKS, pada tahap pasca LKS meningkat menjadi $79,46 \%$.
\end{abstract}

\section{Kata kunci: konsep, larutan penyangga, pengaruh, pemahaman}

\section{Pendahuluan}

Ilmu kimia merupakan salah satu rumpun dari kelompok mata pelajaran ilmu sains yang mempelajari struktur, susunan, sifat, serta energi yang menyertai perubahan materi (Depdiknas, 2003). Menurut Kean. E \& Middlecamp. C. dalam Luh Mentari (2014) Pelajaran kimia sebagai bagian dari Ilmu Pengetahuan Alam (IPA), masih dianggap sebagai mata pelajaran yang sulit oleh sebagian siswa. Salah satu materi pokok yang dipelajari di SMA kelas XI dalam mata pelajaran kimia adalah materi Larutan Penyangga. Cakupan konsep untuk materi larutan penyangga meliputi sifat larutan penyangga, $\mathrm{pH}$ larutan penyangga, dan peranannya dalam tubuh makhluk hidup (Kurikulum 2013). Luh Mentari, dkk (2014) menemukan bahwa miskonsepsi yang terjadi pada konsep-konsep materi larutan penyangga disebabkan oleh beberapa faktor bersumber dari siswa, guru dan bahan ajar. Beberapa faktor penyebab miskonsepsi yang bersumber dari siswa adalah cara belajar siswa lebih banyak menghafal bukan memahami konsep. Menurut Bruner dalam Suryadi (2010) berpandangan bahwa belajar, merefleksikan suatu proses sosial yang di dalamnya anak terlibat dalam dialog dan diskusi baik dengan diri mereka sendiri maupun orang lain termasuk guru sehingga mereka berkembang secara intelektual. Bentuk-bentuk aktivitasnya antara lain bisa berupa interaksi siswa-siswa atau siswa-guru, memanipulasi benda-benda kongkrit seperti alat peraga, dan menggunakan bahan ajar tertentu seperti buku, LKS, modul dan alat-alat teknologi (Suryadi. 2010). Lembar kerja siswa (LKS) merupakan salah satu bahan ajar yang umum digunakan oleh guru 
dalam proses pembelajaran. Lembar kerja siswa dapat memudahkan siswa dalam belajar, melatih siswa dalam menemukan dan mengembangkan keterampilan. Lembar kerja siswa adalah salah satu bentuk program berlandaskan atas tugastugas yang harus diselesaikan dan berfungsi sebagai alat untuk menstimulasi pengetahuan dan keterampilan (Triyanto. 2009).

Berdasarkan pemaparan di atas maka peneliti tertarik melakukan penelitian bagaimana pengaruh penggunaan LKS BAHALAP terhadap pemahaman konsep larutan penyangga pada siswa kelas XI IPA SMAN 3 Palangka Raya tahun ajaran 2018/2019.

Penelitian ini bertujuan untuk mendeskripsikan pengaruh penggunaan LKS BAHALAP terhadap pemahaman konsep pemahaman larutan penyangga pada siswa kelas XI IPA SMAN 3 Palangka Raya tahun ajaran 2018/2019.

\section{Metode Penelitian}

Penelitian ini dilaksanakan di SMA Negeri 3 Palangka Raya yang beralamat di Jl. G. Obos, Kelurahan Menteng, Kecamatan Jekan Raya, Kota Palangka Raya. Adapun subjek penelitiannya adalah 28 siswa di kelas XI MIPA 1 SMAN 3 Palangka Raya Tahun ajaran 2018/2019 kota Palangka Raya, Provinsi Kalimantan Tengah. Pengambilan data penelitian ini dilakukan di SMAN 3 Palangka Raya pada hari Kamis tanggal 28 Februari 2019 di kelas XI MIPA 1 diikuti 28 siswa sesuai dengan waktu yang digunakan saat pembelajaran kimia yaitu 2 x 45 menit ( 2 jam pelajaran). 28 siswa tersebut dibagi menjadi kelompok besar berdasarkan kelompok atas, kelompok sedang (KS), dan kelompok bawah $(\mathrm{KB})$.

Data dalam penelitian dikumpulkan dengan cara pemberian tes pemahaman konsep siswa berupa hasil jawaban siswa pada saat: pra LKS, saat penggunaan LKS, pasca LKS, diskusi, dan pasca diskusi, sedangkan pola jawaban siswa diperoleh berdasarkan pola jawaban siswa yang menjawab salah dari hasil tes semua instrumen.

Teknik analisis data dalam penelitian ini adalah data tes pemahaman konsep larutan penyangga berupa hasil pra LKS, hasil saat pemberian LKS, hasil pasca LKS, diskusi, dan pasca diskusi dianalisis secara deskriptif dengan langkahlangkah sebagai berikut:

1. Hasil jawaban siswa dikelompokkan berdasarkan kelas atas, kelas sedang, dan kelas bawah, kemudian diberikan skor disetiap tahap pembelajaran dan untuk setiap butir soal pada hasil pekerjaan siswa. Pemberian skor setiap butir soal disesuaikan dengan rubrik penilaian, hal ini bertujuan untuk diperoleh data skor. Pengelompokkan siswa kelas atas, kelas sedang, dan kelas bawah secara berturut-turut adalah sebagai berikut: KA: $27 \%$ x $\sum$ siswa, KS: $46 \%$ x $\sum$ siswa, KB: $27 \%$ x $\sum$ siswa. 
2. Skor siswa yang berhasil memperoleh skor lebih besar, lebih kecil, atau sama digolongkan dengan Ketuntasan Belajar Minimum (KBM). Nilai KBM mata pelajaran kimia kelas XI MIPA SMA Negeri 3 Palangka Raya adalah 78.

3. Jawaban salah siswa dikelompokkan berdasarkan pola jawaban siswa.

4. Peningkatan rata-rata pemahaman konsep siswa untuk setiap pertanyaan dideskripsikan dengan membandingkan persentase pemahaman konsep siswa dari pelaksanaan pra LKS, saat pemberian LKS, pasca LKS, diskusi, dan pasca diskusi. Persentase hasil jawaban siswa pada setiap tahap pembelajaran dianalisis menggunakan rumus sebagai berikut:

$\%$ siswa yang menjawab benar $=\frac{\sum \text { siswa men jawab benar }}{\sum \text { seluruh siswa }} \times 100 \%$

Pola jawaban siswa disajikan dalam bentuk tabel dengan persentase pola jawaban salah siswa dirumuskan sebagai berikut:

$\%$ siswa yang menjawab salah $=\frac{\sum \text { siswa menjawab salah }}{\sum \text { seluruh siswa }} \times 100 \%$

5. Pola jawaban siswa dianalisis pada setiap tahap pelaksanaan untuk mengetahui kesalahan yang dominan dilakukan oleh siswa, sehingga dapat dilaporkan pengaruh pemberian LKS terhadap perubahan pemahaman siswa pada materi konsep larutan penyangga.

6. Pengaruh LKS terhadap perubahan pemahaman konsep siswa terjadi jika skor siswa pada tahap pasca LKS lebih besar dibandingkan tahap pra LKS dan skor siswa pada tahap pasca diskusi lebih besar dibandingkan tahap pasca LKS.

\section{Hasil Penelitian Dan Pembahasan}

Berdasarkan kriteria tingkat KBI yang diusulkan oleh Lawson, tingkat perkembangan mahasiswa digolongkan menjadi dua yaitu tingkat concrete dan low formal. Belum ada mahasiswa yang telah mencapai tingkat Upper formal dan Post formal. Tingkat perkembangan KBI mahasiwa disajikan pada Tabel 1, sedangkan grafik skor total KBI berdasarkan jenis penalaran disajikan pada Gambar 1.

Perubahan pemahaman konsep siswa yang menjadi bahasan utama meliputi tahap pra LKS, pasca LKS, dan pasca diskusi. Hal ini dikarenakan tahap saat LKS dan tahap diskusi merupakan data proses pembelajaran dan hanya sebagai data fakta penjelas atau pendukung saja, jadi pada grafik tidak dicantumkan. Tahap pra LKS, pasca LKS, dan pasca diskusi merupakan data dari hasil pembelajaran, jadi hanya tahap pra LKS, pasca LKS, dan pasca diskusi yang dideskripsikan.

Tabel 1 dan Gambar 1 berikut menunjukkan data hasil penelitian jawaban benar siswa semua indikator dalam menjawab soal-soal pada tahap Pra LKS, Pasca LKS, dan Pasca Diskusi. 
Tabel 1. Data Jawaban Benar Siswa dari Pra LKS, Pasca LKS, dan Pasca Diskusi

\begin{tabular}{|c|c|c|c|c|c|c|c|}
\hline \multirow{2}{*}{ Tahap } & \multirow{2}{*}{$\frac{\text { Indikator 1 (\%) }}{1}$} & \multirow{2}{*}{$\mathbf{R}(\%)$} & \multicolumn{4}{|c|}{ Indikator $2(\%)$} & \multirow{2}{*}{$\mathbf{R}(\%)$} \\
\hline & & & 2 & 3 & 4 & 5 & \\
\hline Pra LKS & 7,14 & 7,14 & 42,86 & & & & 42,86 \\
\hline Pasca LKS & 60,71 & 60,71 & 100 & 100 & 92,86 & 53,57 & 86,61 \\
\hline Pasca Diskusi & 67,86 & 67,86 & 92,86 & 96,43 & 67,85 & 75 & 83,04 \\
\hline
\end{tabular}

Lanjutan Tabel 1. Data Jawaban Benar Siswa dari Pra LKS, Pasca LKS, dan Pasca Diskusi

\begin{tabular}{|c|c|c|c|c|c|c|}
\hline Indikator & \multicolumn{5}{|c|}{ Indikator 3 (\%) } & \multirow{2}{R}{} \\
\cline { 2 - 6 } Tahap & $\mathbf{3}$ & $\mathbf{4}$ & $\mathbf{5}$ & $\mathbf{6}$ & $\mathbf{7}$ & $(\boldsymbol{\%})$ \\
\hline Pra LKS & 39,29 & & & & & 39,29 \\
\hline Pasca LKS & & & & 100 & & 100 \\
\hline Pasca Diskusi & & & & 100 & 92,86 & 96,43 \\
\hline
\end{tabular}

Lanjutan Tabel 1. Data Jawaban Benar Siswa dari Pra LKS, Pasca LKS, dan Pasca Diskusi

\begin{tabular}{|c|c|c|c|c|c|c|c|c|c|}
\hline \multirow{2}{*}{ Tahap $_{\text {Indikator }}^{\text {Indis }}$} & \multicolumn{7}{|c|}{ Indikator 4 (\%) } & \multirow{2}{*}{$\underset{(\%)}{R}$} & \multirow{2}{*}{$\begin{array}{c}\mathbf{R r} \\
(\%)\end{array}$} \\
\hline & 4 & 5 & 6 & 7 & 8 & 9 & 10 & & \\
\hline Pra LKS & 28,57 & 25 & & & & & & 26,79 & 29,02 \\
\hline Pasca LKS & & & & 100 & 75 & 60,71 & 82,14 & 79,46 & 81,69 \\
\hline Pasca Diskusi & & & & & 71,43 & 25 & 64,29 & 53,57 & 75 \\
\hline
\end{tabular}

Keterangan : $\mathrm{Rr}=$ rata-rata semua indikator

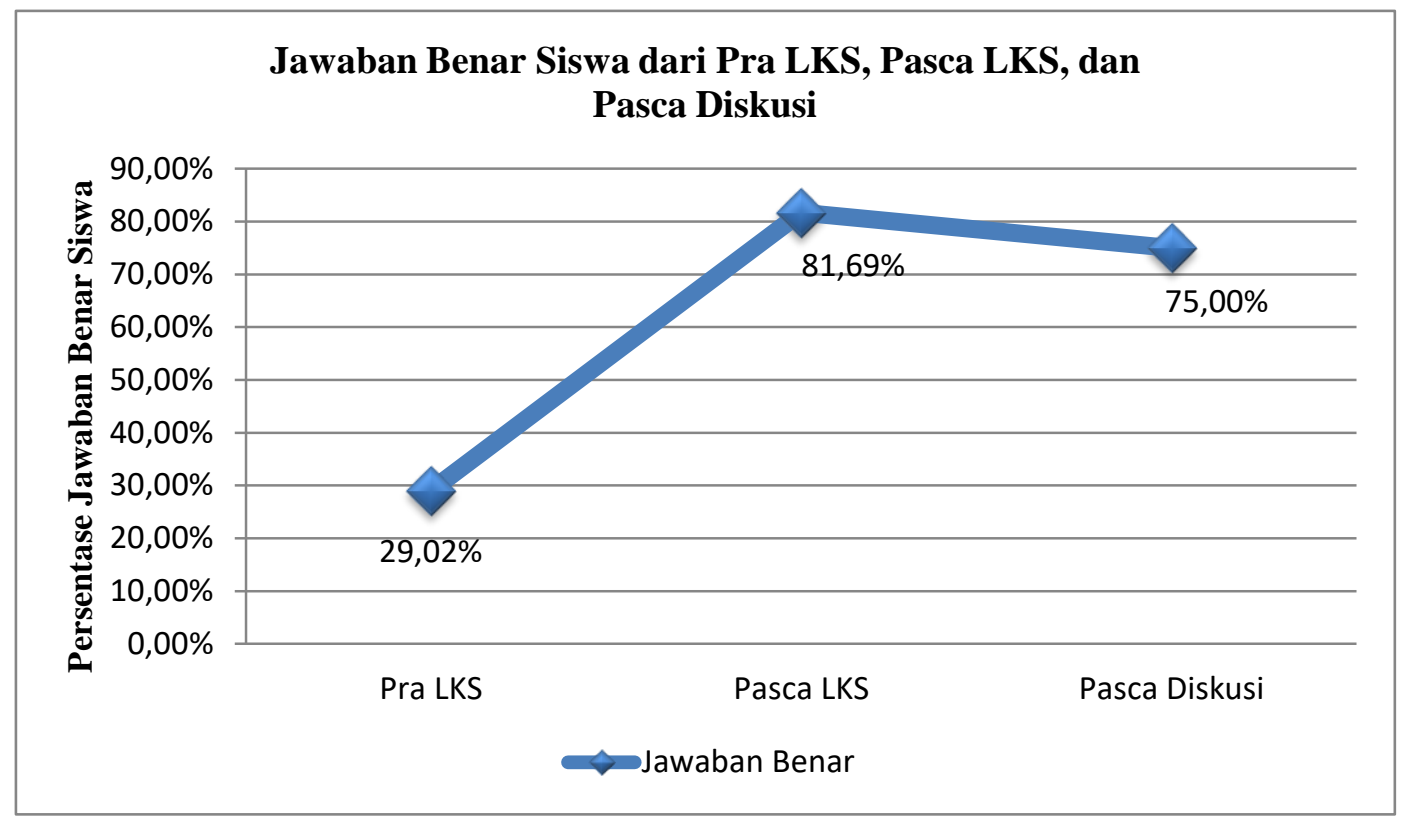

Gambar 1. Grafik Rata-Rata Jawaban Benar Siswa Semua Indikator pada Tahap Pra LKS, Pasca LKS, dan Pasca Diskusi 
Jurnal Ilmiah Kanderang Tingang 10(1) (2019) 81-94 ISSN 2087-166X

Januari-Juni 2019
Fakultas Keguruan dan Ilmu Pendidikan

Universitas Palangka Raya

https://chem-upr.education/ojs

Tabel 2. Persentase Perubahan Jumlah Siswa Menjawab Benar dalam Mengidentifikasi Sifat-Sifat Larutan Penyangga pada Tahap Pra LKS, Pasca LKS, dan Pasca Diskusi

\begin{tabular}{cccc}
\hline \multirow{2}{*}{ Jawaban benar } & Pra LKS & Pasca LKS & Pasca Diskusi \\
\cline { 2 - 4 } $\begin{array}{l}\text { Mengidentifikasi sifat- } \\
\text { sifat larutan penyangga }\end{array}$ & $7,14 \%$ & $60,71 \%$ & $67,86 \%$ \\
\hline
\end{tabular}

Tabel 2 menunjukkan persentase siswa yang dapat mengidentifikasi sifatsifat larutan penyangga. Berikut ditampilkan grafik persentase perubahan jumlah siswa yang menjawab benar dalam mengidentifikasi sifat-sifat larutan penyangga pada tahap pra LKS, pasca LKS, dan pasca diskusi.

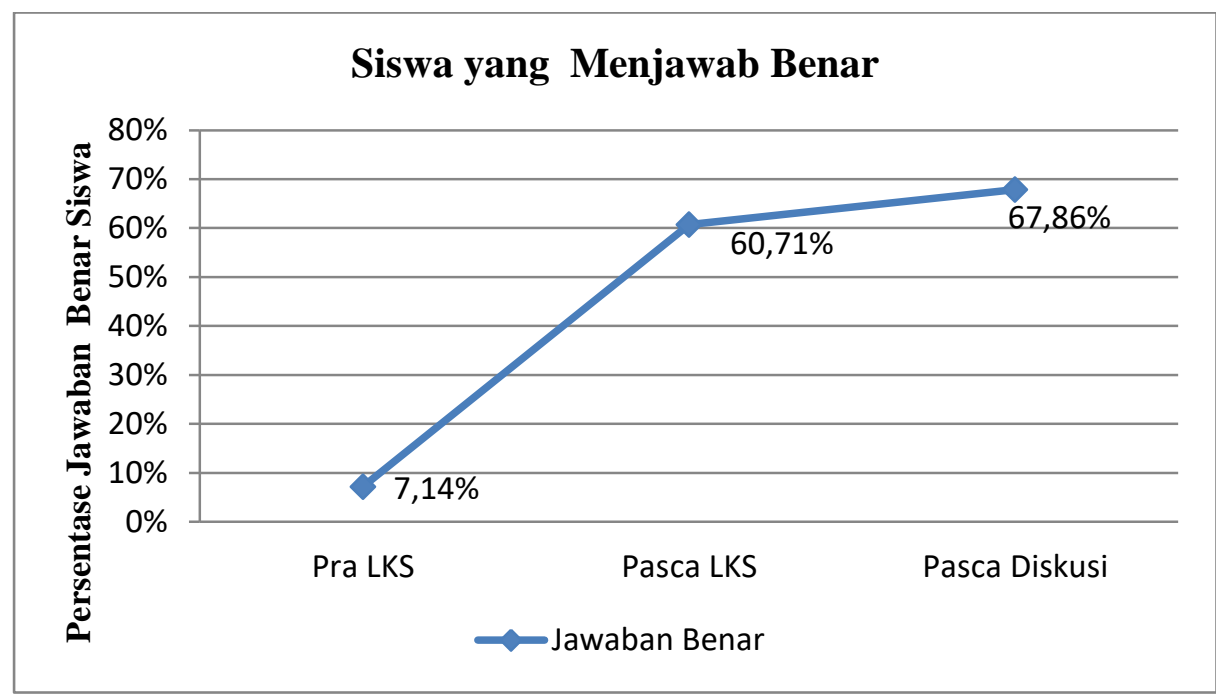

Gambar 2. Grafik Persentase Perubahan Jumlah Siswa Menjawab Benar dalam Mengidentifikasi Sifat-sifat Larutan Penyangga pada Tahap Pra LKS, Pasca LKS, dan Pasca Diskusi

Tabel 2 dan Gambar 2 menunjukkan siswa yang menjawab benar dalam mengidentifikasi sifat-sifat larutan penyangga pada tahap Pra LKS 2 (7,14\%) siswa mampu menjawab benar. Pada tahap pasca LKS siswa yang menjawab benar mengalami peningkatan menjadi $17(60,71 \%)$ siswa, kemudian meningkat pada tahap pasca diskusi menjadi $19(67,86 \%)$ siswa.

Tabel 3. Persentase Perubahan Jumlah Siswa Menjawab Benar Dalam Mengidentifikasi Sifat-sifat Larutan Penyangga pada Tahap Pra LKS, Pasca LKS, dan Pasca Diskusi Berdasarkan KA, KS, dan KB

\begin{tabular}{lcccc}
\hline \multirow{2}{*}{ Jawaban Benar } & Kelompok & Pra LKS & Pasca LKS & $\begin{array}{c}\text { Pasca } \\
\text { Diskusi }\end{array}$ \\
\cline { 2 - 5 } & & $11,11 \%$ & $66,67 \%$ & $66,67 \%$ \\
\hline $\begin{array}{l}\text { Mengidentifikasi } \\
\text { sifat-sifat larutan } \\
\text { penyangga }\end{array}$ & $\mathrm{KS}$ & $9,09 \%$ & $63,64 \%$ & $63,64 \%$ \\
\cline { 2 - 5 } & $\mathrm{KB}$ & $0 \%$ & $50 \%$ & $75 \%$ \\
\hline
\end{tabular}


Tabel 3 menunjukkan bahwa siswa yang dapat mengidentifikasi sifat-sifat larutan penyangga berdasarkan KA, KS dan KB. Berikut ditampilkan grafik persentase perubahan jumlah siswa yang menjawab benar dalam mengidentifikasi sifat-sifat larutan penyangga pada tahap pra LKS, pasca LKS, dan pasca diskusi berdasarkan KA, KS dan KB.

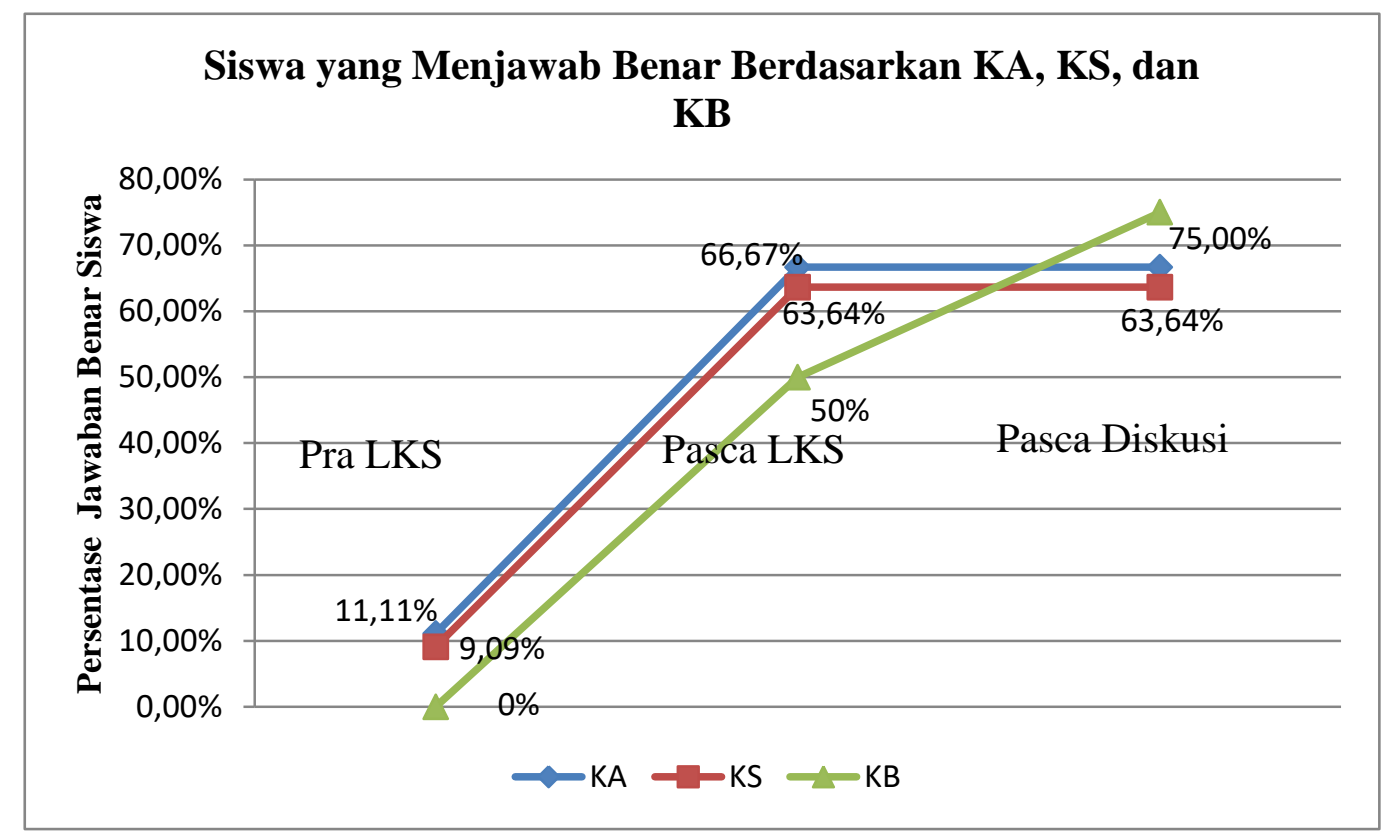

Gambar 3. Grafik Persentase Perubahan Jumlah Siswa yang Menjawab Benar dalam Mengidentifikasi Sifat-sifat Larutan Penyangga pada Tiap Tahap Pra LKS, Pasca LKS, dan Pasca Diskusi Berdasarkan KA, KS, dan KB

Tabel 3 dan Gambar 3 menunjukkan jumlah siswa yang menjawab benar dalam mengidentifikasi sifat-sifat larutan penyangga pada tahap Pra LKS 11,11\% siswa KA dan 9,09\% siswa KS, padahal materi larutan penyangga belum dipelajari siswa yang menjadi subjek penelitian. Hal ini disebabkan siswa tersebut telah memahami makna dari kata larutan penyangga dan telah belajar tentang konsep asam dan basa. 55,55\% siswa KA dan 54,54\% KS mengalami perubahan konsep ke arah yang benar pada tahap pasca LKS, sedangkan untuk siswa KB mengalami perubahan yang cukup signifikan yaitu sebesar $50 \%$. Pada tahap pasca diskusi $66,67 \%$ siswa KA dan 63,64\% siswa KS menjawab benar, sama seperti pada tahap pasca LKS. Adapun siswa KB dapat menjawab dengan benar sebesar $75 \%$, meningkat $25 \%$ dari pasca LKS, hal ini karena adanya pengaruh teman sekelompok yang dilakukan pada tahap diskusi. Berikut adalah deskripsi pola jawaban siswa tiap tahapan pembelajaran.

Perubahan pemahaman konsep siswa yang menjadi bahasan utama meliputi tahap pra LKS, pasca LKS, dan pasca diskusi. Hal ini dikarenakan tahap saat LKS dan tahap diskusi merupakan data proses pembelajaran dan hanya sebagai data fakta penjelas atau pendukung saja, jadi pada grafik tidak 
dicantumkan. Tahap pra LKS, pasca LKS, dan pasca diskusi merupakan data dari hasil pembelajaran, jadi hanya tahap pra LKS, pasca LKS, dan pasca diskusi yang dideskripsikan.

Tabel 4. Persentase Perubahan Jumlah Siswa Menjawab Benar dalam Mengidentifikasi Komponen Pembentuk Larutan Penyangga pada Tahap Pra LKS, Pasca LKS, dan Pasca Diskusi

\begin{tabular}{lccc}
\hline \multirow{2}{*}{ Jawaban benar } & \multicolumn{3}{c}{ Tahap } \\
\cline { 2 - 4 } & Pra LKS & Pasca LKS & Pasca Diskusi \\
\hline $\begin{array}{l}\text { Mengidentifikasi } \\
\text { komponen } \\
\text { pembentuk }\end{array}$ & $42,86 \%$ & $88,61 \%$ & \\
$\begin{array}{l}\text { larutan } \\
\text { penyangga }\end{array}$ & & & \\
\hline
\end{tabular}

Tabel 4 menunjukkan persentase siswa yang dapat menjawab benar dalam mengidentifikasi komponen pembentuk larutan penyangga pada tahap pra LKS, pasca LKS, dan pasca diskusi. Berikut ditambilkan grafik persentase perubahan jumlah siswa menjawab benar dalam mengidentifikasi komponen pembentuk larutan penyangga pada tahap pra LKS, pasca LKS, dan pasca diskusi.

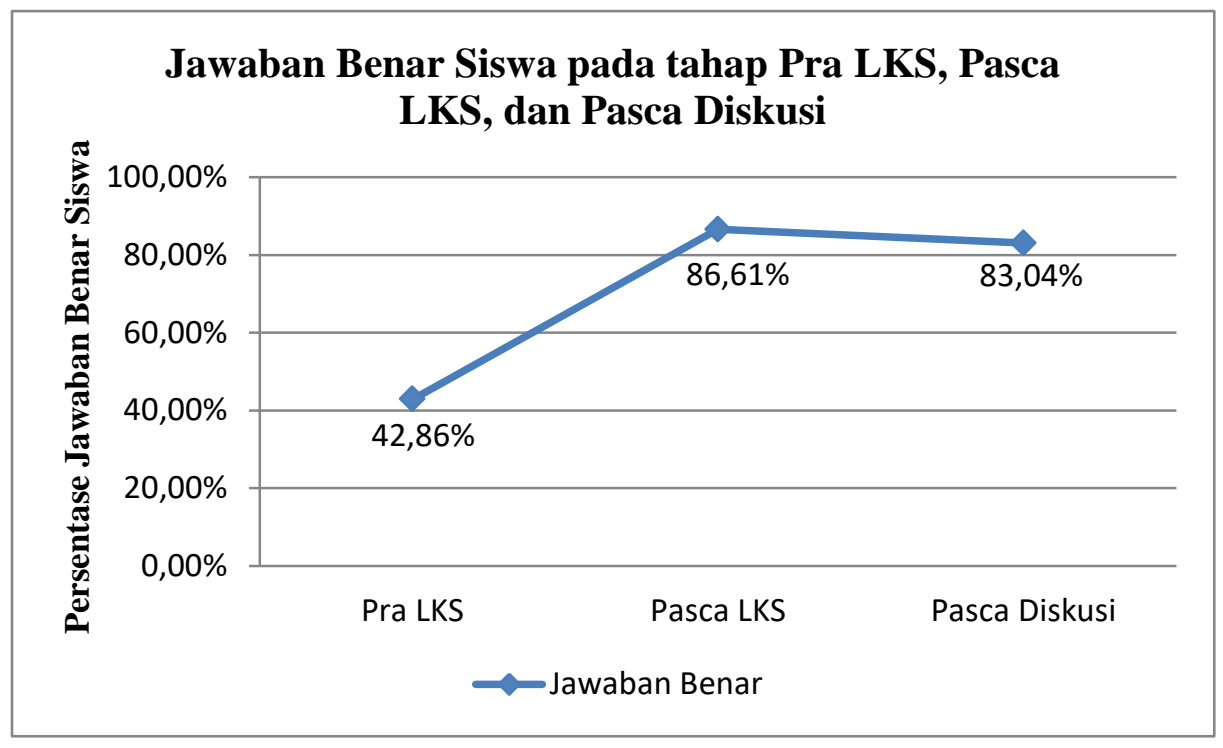

Gambar 4. Grafik Persentase Perubahan Jumlah Siswa Menjawab Benar dalam Mengidentifikasi Komponen Pembentuk Larutan Penyangga pada Tahap Pra LKS, Pasca LKS, dan Pasca Diskusi

Tabel 4 dan Gambar 4 menunjukkan siswa yang menjawab benar dalam mengidentifikasi komponen pembentuk larutan penyangga pada tahap pra LKS, pasca LKS, dan pasca diskusi. Pada tahap Pra LKS soal nomor 2, $12(42,86 \%)$ siswa yang mampu menjawab benar. Pada tahap pasca LKS, siswa yang menjawab benar mengalami peningkatan menjadi $(86,61 \%)$ siswa dengan 
keterangan soal nomor 2 sebanyak $28(100 \%)$ siswa; soal nomor 3 sebanyak 28 (100\%) siswa; soal nomor 4 sebanyak 26 (92,86\%); dan $15(53,57 \%)$ siswa untuk soal nomor 5, maka rata-rata siswa yang menjawab benar 4 soal tersebut adalah $86,61 \%$ siswa. Namun jumlah siswa yang menjawab benar mengalami penurunan pada tahap pasca diskusi yaitu $26(92,86 \%)$ siswa dimana soal nomor 2 sebanyak $26(92,86 \%)$ siswa; soal nomor 3 sebanyak $27(96,43 \%)$ siswa; soal nomor 4 sebanyak $19(67,86 \%)$ siswa; soal nomor 5 sebanyak 21(75\%), maka rata-rata $82,14 \%$ siswa yang mampu menjawab benar 4 soal pada tahap pasca diskusi tersebut.

Tabel 5. Persentase Perubahan Jumlah Siswa Menjawab Benar dalam Mengidentifikasi Komponen Pembentuk Larutan Penyangga pada Tahap Pra LKS, Pasca LKS, dan Pasca Diskusi Berdasarkan KA, KS, dan KB

\begin{tabular}{|c|c|c|c|c|}
\hline \multirow[b]{2}{*}{ Jawaban Benar } & \multirow[b]{2}{*}{ Kelompok } & \multicolumn{3}{|c|}{ Tahap } \\
\hline & & Pra LKS & Pasca LKS & $\begin{array}{c}\text { Pasca } \\
\text { Diskusi }\end{array}$ \\
\hline \multirow{3}{*}{$\begin{array}{l}\text { Mengidentifikasi } \\
\text { komponen } \\
\text { pembentuk } \\
\text { larutan } \\
\text { penyangga }\end{array}$} & KA & $44,44 \%$ & $88,89 \%$ & $86,11 \%$ \\
\hline & $\mathrm{KS}$ & $36,36 \%$ & $84,09 \%$ & $81,82 \%$ \\
\hline & $\mathrm{KB}$ & $50 \%$ & $87,50 \%$ & $81,25 \%$ \\
\hline
\end{tabular}

Tabel 5 menunjukkan persentase siswa yang dapat menjawab benar dalam mengidentifikasi komponen pembentuk larutan penyangga pada tahap pra LKS, pasca LKS, dan pasca diskusi berdasarkan KA, KS, dan KB. Berikut ditambilkan grafik persentase perubahan jumlah siswa menjawab benar dalam mengidentifikasi komponen pembentuk larutan penyangga pada tahap pra LKS, pasca LKS, dan pasca diskusi berdasarkan KA, KS, dan KB.

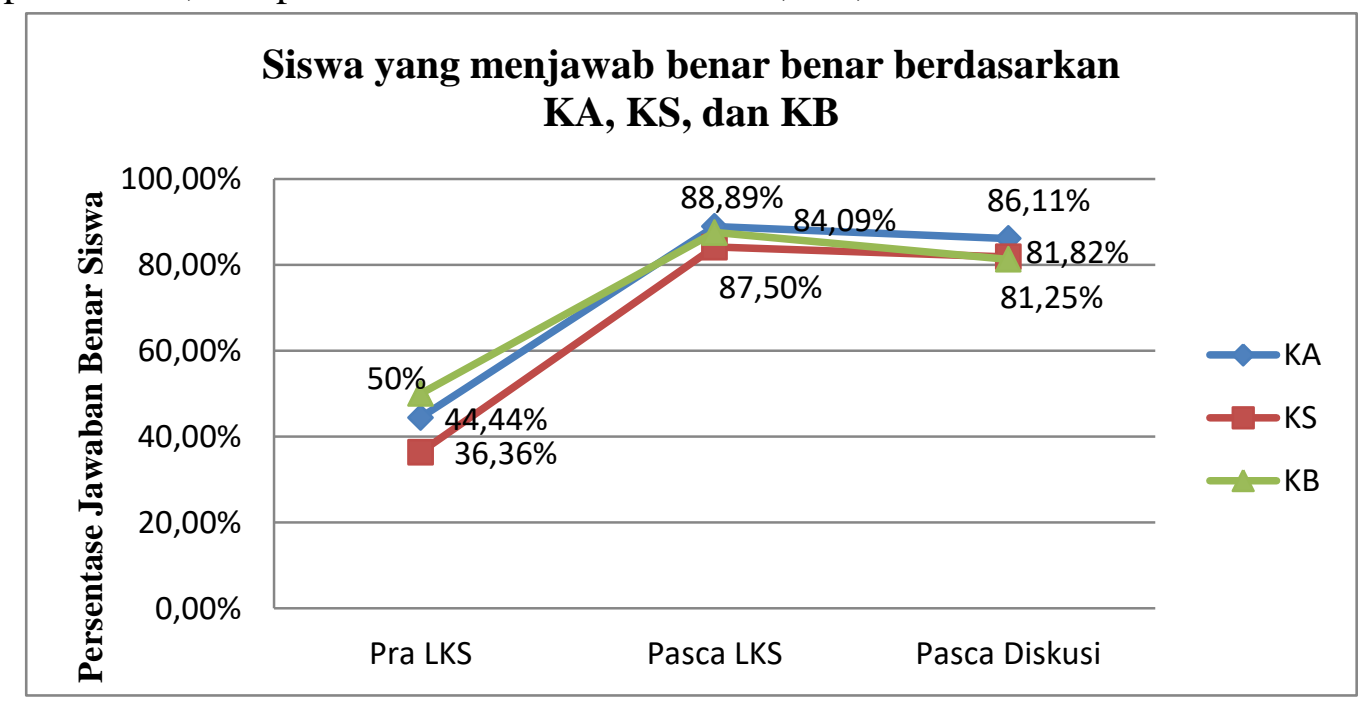

Gambar 5. Grafik Persentase Perubahan Jumlah Siswa Menjawab Benar dalam Mengidentifikasi Komponen Pembentuk Larutan Penyangga pada Tahap Pra LKS, Pasca LKS, dan Pasca Diskusi Berdasarkan KA, KS, dan KB 
Tabel 5 dan Gambar 5 menunjukkan jumlah siswa yang menjawab benar dalam mengidentifikasi komponen pembentuk larutan penyangga. Berdasarkan Tabel 5 dan Gambar 5 tersebut siswa KA, KS, dan KB berturut-turut mengalami perubahan konsep ke arah yang benar pada tahap pasca LKS sebesar 88,89\%, $84,09 \%$, dan $87,50 \%$. Hal ini berarti LKS berpengaruh terhadap KA, KS dan KB. Namun, jawaban benar siswa KA, KS dan KB pada tahap pasca diskusi mengalami penurunan dengan persentase berturut-turut yakni 86,11\%, 81,82\%, $81,82 \%$. Hal ini terjadi karena antar siswa KA, KS maupun KB mendapat pengaruh teman sekelompoknya yang dilakukan pada tahap diskusi. Berikut adalah deskripsi pola jawaban siswa tiap tahapan pembelajaran.

Perubahan pemahaman konsep siswa yang menjadi bahasan utama meliputi tahap pra LKS, pasca LKS, dan pasca diskusi. Hal ini dikarenakan tahap saat LKS dan tahap diskusi merupakan data proses pembelajaran dan hanya sebagai data fakta penjelas atau pendukung saja, jadi pada grafik tidak dicantumkan. Tahap pra LKS, pasca LKS, dan pasca diskusi merupakan data dari hasil pembelajaran, jadi hanya tahap pra LKS, pasca LKS, dan pasca diskusi yang dideskripsikan.

Tabel 6. Persentase Perubahan Jumlah Siswa Menjawab Benar dalam Menentukan Zat dan Jumlahnya yang Dapat Membentuk Larutan Penyangga pada Tahap Pra LKS, Pasca LKS, dan Pasca Diskusi

\begin{tabular}{lccc}
\multicolumn{1}{c}{ Jawaban benar } & Pra LKS & Pasca LKS & Pasca Diskusi \\
\cline { 2 - 4 } $\begin{array}{l}\text { Menentukan zat dan } \\
\text { jumlahnya yang dapat } \\
\text { membentuk larutan } \\
\text { penyangga }\end{array}$ & $39,29 \%$ & $100 \%$ & $96,43 \%$ \\
\hline
\end{tabular}

Tabel 6 menunjukkan persentase siswa yang menjawab benar dalam menentukan zat dan jumlahnya yang dapat membentuk larutan penyangga pada tahap pra LKS, pasca LKS, dan pasca diskusi. Berikut ditampilkan grafik persentase perubahan jumlah siswa yang menjawab benar dalam menentukan zat dan jumlahnya yang dapat membentuk larutan penyangga pada tahap pra LKS, pasca LKS, dan pasca diskusi.

Tabel 6 dan Gambar 6 menunjukkan siswa yang menjawab benar dalam menentukan zat dan jumlahnya yang dapat membentuk larutan penyangga tahap Pra LKS pada soal nomor 3, $11(39,29 \%)$ siswa mampu menjawab benar. Pada tahap pasca LKS soal nomor 6 sebanyak 28 (100\%) siswa menjawab benar. Lalu di tahap pasca diskusi menjadi pada soal nomor 6 sebanyak $28(100 \%)$ siswa menjawab benar dan pada soal nomor 7 sebanyak $26(92,56 \%)$ siswa menjawab benar. 


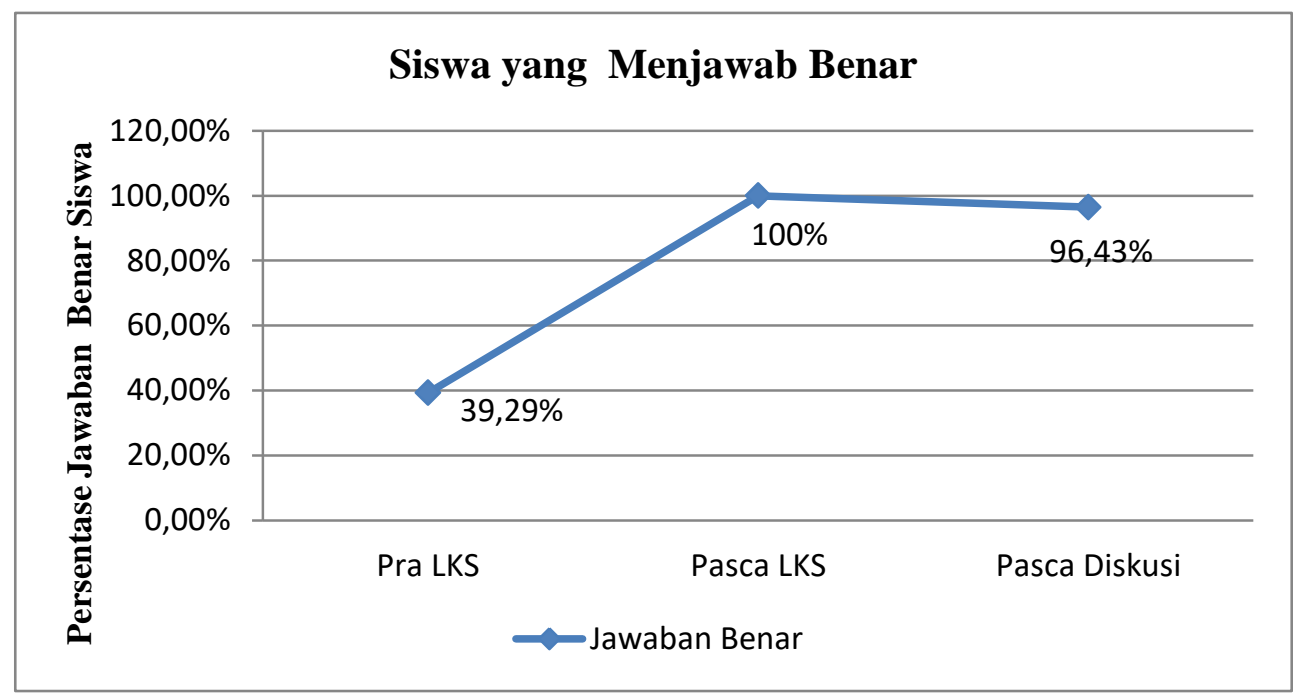

Gambar 6. Grafik Persentase Perubahan Jumlah Siswa Menjawab Benar dalam Menentukan Zat dan Jumlahnya yang Dapat Membentuk Larutan Penyangga pada Tahap Pra LKS, Pasca LKS, dan Pasca Diskusi

Tabel 7. Persentase Perubahan Jumlah Siswa Menjawab Benar Dalam Mengidentifikasi Zat dan Jumlahnya yang dapat Membentuk Larutan Penyangga pada Tahap Pra LKS, Pasca LKS, dan Pasca Diskusi Berdasarkan $\mathrm{KA}, \mathrm{KS}$, dan $\mathrm{KB}$

\begin{tabular}{lcccc}
\hline \multirow{2}{*}{ Jawaban Benar } & Kelompok & \multicolumn{3}{c}{ Tahap } \\
\cline { 3 - 5 } & & Pra LKS & Pasca LKS & $\begin{array}{c}\text { Pasca } \\
\text { Diskusi }\end{array}$ \\
\hline $\begin{array}{l}\text { Mengidentifikasi zat dan } \\
\text { jumlahnya yang dapat } \\
\text { membentuk larutan } \\
\text { penyangga }\end{array}$ & KA & $44,44 \%$ & $100 \%$ & $88,89 \%$ \\
\cline { 2 - 5 } & KS & $45,45 \%$ & $100 \%$ & $100 \%$ \\
\hline
\end{tabular}

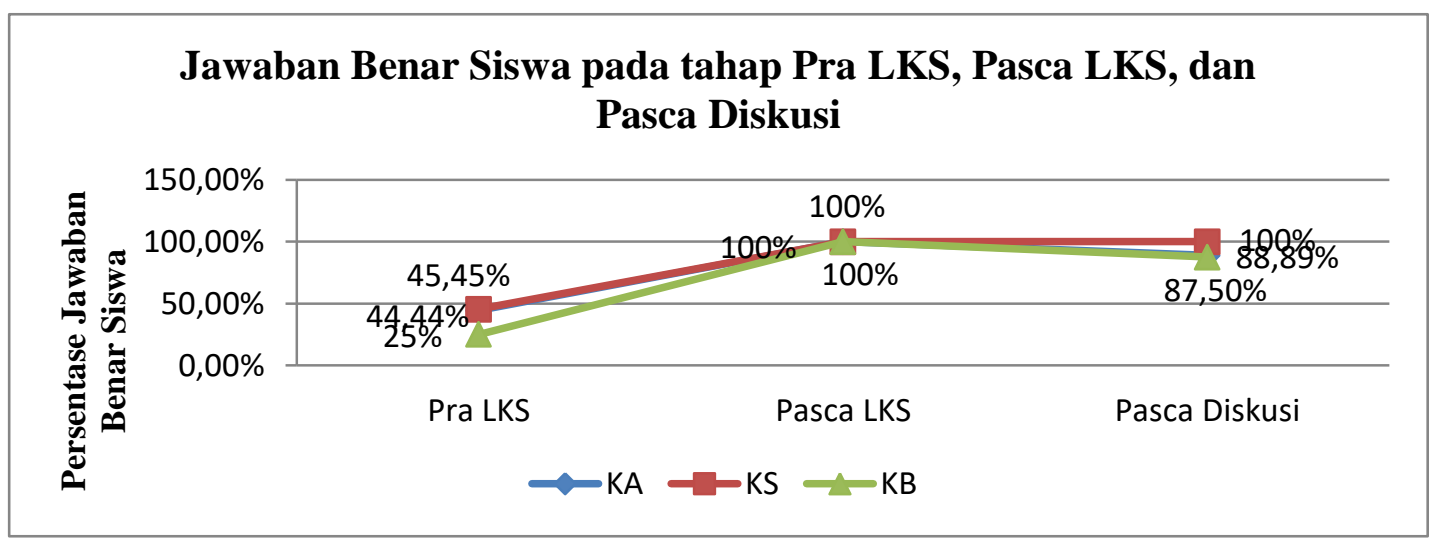

Gambar 7. Grafik Persentase Perubahan Jumlah Siswa yang Menjawab Benar dalam Menentukan Zat Dan Jumlahnya Yang Dapat Membentuk Larutan Penyangga pada Tiap Tahap Pra LKS, Pasca LKS, dan Pasca Diskusi Berdasarkan KA, KS, dan KB 
Tabel 7 menunjukkan persentase siswa yang menjawab benar dalam menentukan zat dan jumlahnya yang dapat membentuk larutan penyangga pada tahap pra LKS, pasca LKS, dan pasca diskusi berdasarkan KA, KS, dan KB. Berikut ditampilkan grafik persentase perubahan jumlah siswa yang menjawab benar dalam menentukan zat dan jumlahnya yang dapat membentuk larutan penyangga pada tahap pra LKS, pasca LKS, dan pasca diskusi berdasarkan KA, $\mathrm{KS}$, dan KB.

Tabel 7 dan Gambar 7 menunjukkan jumlah siswa yang menjawab benar dalam menentukan zat dan jumlahnya yang dapat membentuk larutan penyangga. Berdasarkan Tabel 7 dan Gambar 7 tersebut pada tahap Pra LKS soal nomor 3 sebanyak $4(44,44 \%)$ siswa KA, $5(45,45 \%)$ siswa KS, dan $2(25 \%)$ siswa KB. Soal nomor 6 pasca LKS siwa yang menjawab benar sebanyak 9 (100\%) siswa KA, $11(100 \%)$ siswa KS, dan 8 (100\%) siswa KB. Adapun untuk pasca diskusi siswa yang menjawab benar untuk soal nomor 6 sebanyak 9 (100\%) siswa KA, 11 $(100 \%)$ siswa KS, dan $8(100 \%)$ siswa KB; untuk soal nomor 7 sebanyak 8 $(88,89 \%)$ siswa KA, $11(100 \%)$ siswa KS, dan 7 (87,50\%) siswa KB.

Perubahan pemahaman konsep siswa yang menjadi bahasan utama meliputi tahap pra LKS, pasca LKS, dan pasca diskusi. Hal ini dikarenakan tahap saat LKS dan tahap diskusi merupakan data proses pembelajaran dan hanya sebagai data fakta penjelas atau pendukung saja, jadi pada grafik tidak dicantumkan.

Tabel 8. Persentase Perubahan Jumlah Siswa Menjawab Benar dalam Menghitung pH Larutan Penyangga pada Tahap Pra LKS, Pasca LKS, dan Pasca Diskusi

\begin{tabular}{lccc}
\hline \multicolumn{1}{c}{ Jawaban benar } & \multicolumn{3}{c}{ Tahap } \\
\cline { 2 - 4 } & Pra LKS & Pasca LKS & Pasca Diskusi \\
\hline $\begin{array}{l}\text { Menghitung } \mathrm{pH} \\
\text { larutan penyangga }\end{array}$ & $26,79 \%$ & $79,46 \%$ & $53,57 \%$ \\
\hline
\end{tabular}

Tabel 8 menunjukkan siswa yang dapat mengitung $\mathrm{pH}$ larutan penyangga pada tahap pra LKS, pasca LKS, dan pasca diskusi. Berikut ditampilkan grafik persentase perubahan jumlah siswa yang menjawab benar dalam mengitung $\mathrm{pH}$ larutan penyangga pada tahap pra LKS, pasca LKS, dan pasca diskusi.

Tabel 8 dan Gambar 8 menunjukkan siswa yang menjawab benar dalam menghitung $\mathrm{pH}$ larutan penyangga pada tahap pra LKS untuk soal nomor 4 sebanyak $8(28,57 \%)$ dan untuk soal nomor 5 sebanyak 7 (25\%) siswa. Pada tahap pasca LKS siswa yang menjawab benar mengalami peningkatan menjadi 28 (100\%) siswa pada soal nomor 7, $21(75 \%)$ siswa pada soal nomor 8, $17(60,71 \%)$ siswa pada soal nomor 9, $23(82,14 \%)$ siswa pada soal nomor 10 . Namun, mengalami penurunan pada tahap pasca diskusi yaitu $20(71,43 \%)$ siswa pada soal nomor $8,7(25 \%)$ siswa pada soal nomor 9, $18(64,29 \%)$ siswa pada soal nomor 10. 


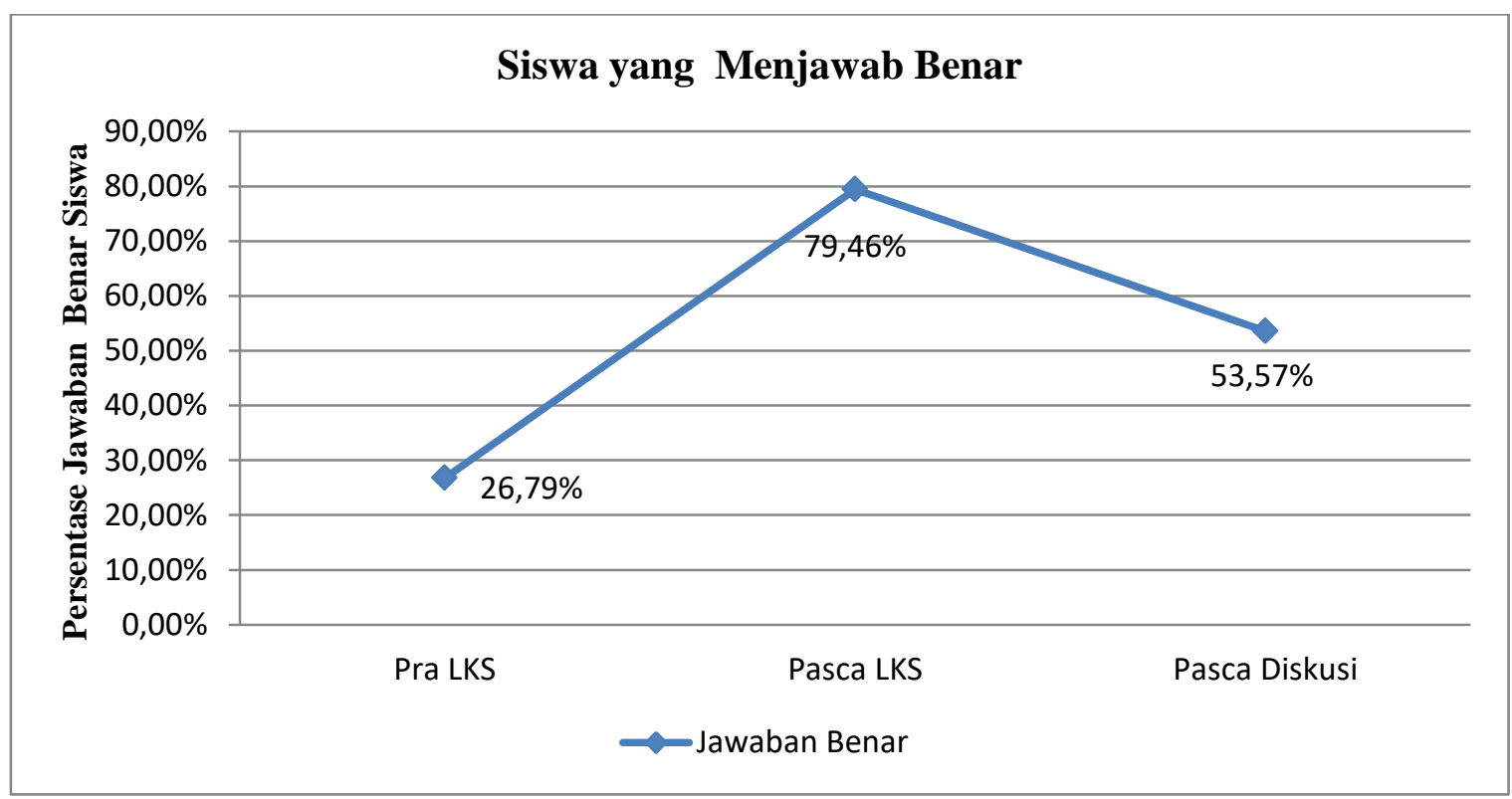

Gambar 8. Grafik Persentase Perubahan Jumlah Siswa Menjawab Benar dalam Menghitung pH Larutan Penyangga pada pada Tahap Pra LKS, Pasca LKS, dan Pasca Diskusi

Tabel 9. Persentase Perubahan Jumlah Siswa Menjawab Benar Dalam Menghitung pH Larutan Penyangga pada pada Tahap Pra LKS, Pasca LKS, dan Pasca Diskusi Berdasarkan KA, KS, dan KB

\begin{tabular}{lcccc}
\hline \multirow{2}{*}{ Jawaban Benar } & \multirow{2}{*}{ Kelompok } & \multicolumn{3}{c}{ Tahap } \\
\cline { 2 - 5 } & & Pra LKS & Pasca LKS & Pasca Diskusi \\
\cline { 2 - 5 } $\begin{array}{l}\text { Menghitung pH } \\
\text { larutan penyangga }\end{array}$ & $\mathrm{KA}$ & $33,33 \%$ & $80,56 \%$ & $53,56 \%$ \\
\cline { 2 - 5 } & $\mathrm{KS}$ & $36,36 \%$ & $79,54 \%$ & $51,51 \%$ \\
\hline
\end{tabular}

Tabel 9 menunjukkan bahwa siswa yang dapat mengitung $\mathrm{pH}$ larutan penyangga pada tahap pra LKS, pasca LKS, dan pasca diskusi berdasarkan KA, KS, dan KB. Berikut ditampilkan grafik persentase perubahan jumlah siswa yang menjawab benar dalam mengitung $\mathrm{pH}$ larutan penyangga pada tahap pra LKS, pasca LKS, dan pasca diskusi berdasarkan KA, KS, dan KB.

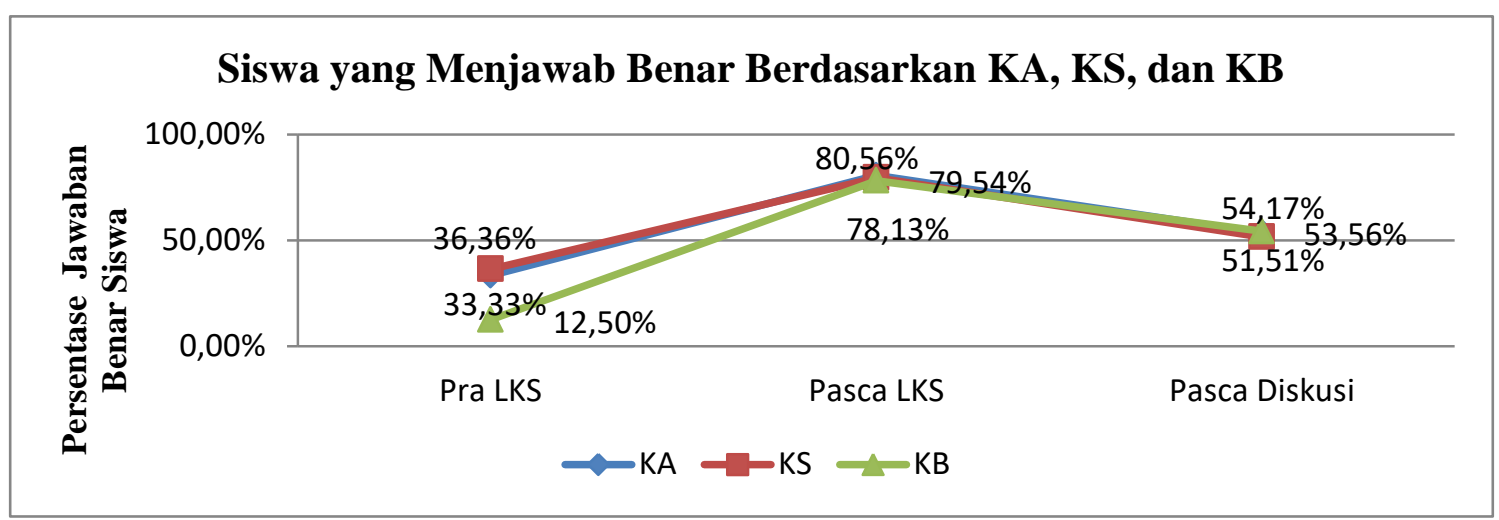

Gambar 9. Grafik Persentase Perubahan Jumlah Siswa yang Menjawab Benar dalam Menghitung $\mathrm{pH}$ Larutan Penyangga pada pada Tiap Tahap Pra LKS, Pasca LKS, dan Pasca Diskusi Berdasarkan KA, KS, dan KB 
Tabel 9 dan Gambar 9 menunjukkan jumlah siswa yang menjawab benar dalam menghitung pH penyangga. Berdasarkan Tabel 9 dan Gambar 9 tersebut pada tahap pra LKS 33,33\% siswa KA dan 36,36\% siswa KS, dan 12,50\% siswa KB. Terjadi peningkatan $80,56 \%$ siswa KA, 79,54\% siswa KS, dan 78,13\% siswa KB mengalami perubahan konsep ke arah yang benar pada tahap pasca LKS. Pada tahap pasca diskusi turun menjadi 55,56\% siswa KA, 51,51\% siswa KS, dan $54,17 \%$ siswa KB. Berikut adalah deskripsi pola jawaban siswa tiap tahapan pembelajaran.

\section{Kesimpulan}

Kesalahan siswa dalam menentukan sifat-sifat larutan penyangga pada tahap pra LKS adalah siswa menganggap bahwa: (1) larutan penyangga dibuat dari bukan campuran asam lemah dan basa konjugasinya, (2) konsentrasi asam dan basa konjugasi sama banyak maka sifat larutan penyangga semakin tidak efisien, (3) jika sedikit diencerkan larutan penyangga akan berubah harga pHnya, (4) larutan penyangga tidak dapat dibuat dari asam lemah diprotik seperti $\mathrm{H}_{2} \mathrm{CO}_{3}$ dan $\mathrm{NaHCO}_{3}$.

Kesalahan siswa dalam menentukan komponen pembentuk larutan penyangga pada tahap pra LKS adalah siswa menganggap bahwa: (1) pasangan asam kuat dan garam lain merupakan pasangan asam lemah dan garam senamanya yang dapat membentuk larutan penyangga, (2) pasangan asam kuat dan garamnya merupakan pasangan asam lemah dan garamnya yang dapat membentuk larutan penyangga, (3) pasangan asam lemah dan garam lain merupakan pasangan asam lemah dan garam senamnya yang dapat membentuk larutan penyangga, (4) siswa tidak memahami pasangan asam dan garam senama yang dapat membentuk larutan penyangga.

Kesalahan siswa dalam menentukan zat dan jumlahnya yang dapat membentuk larutan penyangga pada tahap pra LKS adalah: (1) siswa menduga zat yang merupakan komponen penyangga adalah zat mula-mula, tanpa mengitung mol zat yang bereaksi agar mengetahui zat hasil akhir reaksinya, (2) siswa kesulitan membedakan antara asam kuat dengan asam lemah; membedakan antara basa kuat dan basa lemah sehingga siswa sulit menentukan pasangan yang dapat membentuk larutan penyangga.

Kesalahan siswa dalam menghitung $\mathrm{pH}$ larutan penyangga adalah: (1) siswa menghitung $\mathrm{pH}$ larutan penyangga dengan mengoperasikan asam lemah dan basa kuat tanpa melibatkan komponen garam/basa konjugasi, (2) siswa tidak mengurangkan nilai $\mathrm{pOH}$ terhadap $\mathrm{pKw}$, (3) siswa tidak memahami bahwa $\mathrm{pH}$ asam $<7$ dan $\mathrm{pH}$ basa $<7$.

Pengaruh penggunaan LKS BAHALAP terhadap pemahaman siswa dalam: (1) Menentukan sifat-sifat larutan penyangga. Tahap pra LKS skor ratarata siswa 7,14\%, pada tahap pasca LKS meningkat menjadi 60,71\%. (2) 
Mengidentifikasi komponen pembentuk larutan penyangga. Tahap pra LKS skor rata-rata siswa $42,86 \%$, pada tahap pasca LKS meningkat menjadi $86,61 \%$. (3) Menentukan zat dan jumlahnya yang dapat membentuk larutan penyangga. Tahap pra LKS skor rata-rata siswa 39,29\%, pada tahap pasca LKS meningkat menjadi $100 \%$. Menghitung $\mathrm{pH}$ larutan penyangga. Tahap pra LKS indikator 4 skor ratarata siswa $26,79 \%$, pada tahap pasca LKS meningkat menjadi 79,46\%.

\section{Daftar Pustaka}

Departermen Pendidikan Nasional. (2003). Garis-Garis Besar Program Pengajaran Ilmu Kimia. Jakarta: Departemen Pendidikan dan Kebudayaan

Mentari, Luh, I Nyoman Suardana dan I Wayan Subagia. 2014. Analisis Miskonsepsi Siswa Sma Pada Pembelajaran Kimia Untuk Materi Larutan Penyangga. Denpasar: Jurusan Pendidikan Kimia Universitas Pendidikan Ganesha Singaraja

Suryadi, didi. 2010. Menciptakan Proses Belajar Aktif: Kajian dari Sudut Pandang Teori Belajar Dan Teori Didaktik 1. Bandung: Jurusan Pendidikan Matematika FPMIPA UPI

Triyanto. 2009. Mendesain Model Pembelajaran Inovatif-Progresif. Jakarta: Kencana Prenada Media Group 